DOI: 10.17117/na.2015.11.02.132

Поступила (Received): 20.11.2015

\title{
Елизарьева Л.В.
}

\section{Квест как форма организации образовательной деятельности в дошкольном учреждении}

\author{
Elizareva L.V. \\ Quest as a form of educational activity in preschool
}

Образовательная деятельность в формате квест замечательно вписывается в концепцию, заданную ФГОС ДО. Квест - это форма взаимодействия педагога и детей, которая способствует формированию умений решать определенные задачи на основе компетентного выбора альтернативных вариантов через реализацию определенного сюжета. Возможность реализации образовательных задач в форме квеста вполне реальна в условиях дошкольного образовательного учреждения с детьми старшего дошкольного возраста

Ключевые слова: квест, педагогическая технология, образовательная деятельность

\section{Елизарьева Людмила Владимировна}

Учитель-логопед

Центр развития ребенка - детский сад «Калинка» Хакасия, г. Абакан, ул. Хакасская, 107
Educational activities in the great quest format fits into the concept, given to the GEF. Quest - a form of interaction between the teacher and the children, which contributes to the ability to solve certain tasks based on informed choices of alternatives through the implementation of a specific plot. The possibility of realization of educational tasks in the form of a quest is very real in the conditions of preschool educational institution with children preschool age

Key words: quest, educational technology, educational activities

\author{
Elizareva Liudmila Vladimirovna \\ Teacher speech therapist \\ Child Development Center - Kindergarten "Kalinka" \\ Khakassia, Abakan, Khakassia st., 107
}

Насыщенная информационная среда окружает современного ребенка с самого его рождения. Все большее место в жизни дошкольника занимают компьютер, игровые приставки, электронные игрушки. Современных детей все сложнее чем- либо удивить. Это, безусловно, накладывает определенный отпечаток на развитие личности ребенка и на формирование его психики. Педагог, учитывая возрастающую конкуренцию со стороны машин, вынужден идти в ногу со временем и применять в своей работе современные средства обучения и развития, новые педагогические методики и технологии, оригинальные формы проведения образовательной деятельности. Одной из новых форм в практике дошкольного образования можно считать квест.

Квест (заимствование англ. Quest - «поиск, предмет поисков, поиск приключений, исполнение рыцарского обета»; изначально - один из способов построения сюжета - путешествие персонажей к определенной цели через преодоление трудностей) [1]. 
Квест - это форма взаимодействия педагога и детей, которая способствует формированию умений решать определенные задачи на основе компетентного выбора альтернативных вариантов через реализацию определенного сюжета.

Любая педагогическая технология предполагает в качестве результата усвоение воспитанниками определённого комплекса знаний, умений, навыков. Сокол И.Н. рассматривает квест как технологию, которая имеет четко поставленную дидактическую задачу, игровой замысел, обязательно имеет руководителя (наставника), четкие правила, и реализуется с целью повышения у детей уровня знаний и умений [5].

По мнению многих ученых (Быховский Я.С., Бовтенко М.А., Сысоев П.В., Б. Додж, Т. Марч и др.) при применении квест-технологии дети проходят полный цикл мотивации: от внимания до удовлетворения, знакомятся с аутентичным материалом, который позволяет им исследовать, обсуждать и осознанно строить новые концепции и отношения в контексте проблем реального мира, создавая проекты, имеющие практическую значимость. Квест, как недавно определившаяся педагогическая технология, совмещает в себе элементы мозгового штурма, тренинга, игры, и соответственно, решает ряд задач, возложенных на вышеперечисленные технологии.

Квест- технология имеет ряд особенностей: образовательная задача осуществляется через игровую деятельность и носит поисковый характер; самовыражению ребенка способствует внедрение новых технических средств обучения; целенаправленно мотивируется эмоциональная и интеллектуальная активности ребенка. Образовательный процесс может быть организован в форме обучающей игры, творческой деятельности, познавательной и поисковой деятельности детей; может быть как индивидуальным, так и коллективным. Роль педагога-наставника в квест-игре организационная, т.е. педагог определяет образовательные цели квеста, составляет сюжетную линию игры, оценивает процесс деятельности детей и конечный результат, организует поисково-исследовательскую образовательную деятельность [4].

Проанализировав разработанную Сокол И.Н. обобщенную классификацию и адаптировав ее к реалиям современного ДОУ, я пришла к выводу, что возможность реализации образовательных задач в формате квеста вполне реальна в условиях дошкольного образовательного учреждения с детьми старшего дошкольного возраста.

По типу образовательных задач (классификация Б.Доджа и Т.Марча) квесты могут иметь следующие формы : перевод - создание презентации, плаката, рассказа по заданной теме; планирование и проектирование - разработка плана или проекта на основе заданных условий; компиляция - трансформация информации, полученной из разных источников: создание книги кулинарных рецептов, виртуальной выставки, и т.д.; творческое задание - творческая работа в определенном жанре - создание пьесы, стихов, песни, рисунка, коллажа; аналитическая задача - поиск и систематизация информации; детектив, головоломка, таинственная история - выводы на основе противоречивых фактов [3]. 
Все вышеперечисленные образовательные задачи могут решаться группой или индивидуально; быть как краткосрочными - одно занятие, так и долгосрочными; проводиться в традиционной, виртуальной или комбинированной образовательной среде; иметь различную структуру сюжета; проводиться как в помещении ДОУ, так и на природе (улица, парк, территория ДОУ) или медиаквесты -поиск и анализ информации в медиаресурсах , либо комбинированные.

Основными критериями качества квеста выступают его безопасность для участников, оригинальность, логичность, целостность, подчинённость определённому сюжету, а не только теме, создание атмосферы игрового пространства. Возможность введения в игру разнообразных заданий позволяет не только решать бесчисленное множество интеллектуальных и творческих задач, но и превращает каждый квест в уникальный продукт. Это может быть: решение ребусов, загадок, кроссвордов, головоломок; игра «крокодил», тематическое прохождение препятствий, создание плаката, коллажа, рекламы-антирекламы, творческую деятельность в техниках аквагрим, боди-арт, перформанс, квиллинг, декупаж и скрапбукинг, поэтические поединки, короткие музыкальные, танцевальные и театральные постановки с элементами психодрамы, тренинговые упражнения и т.д. [5].

Квест - это игровая педагогическая технология. Педагогами и психологами давно доказано, что хорошо организованная игра сама по себе - лучшее средство достижения детьми эстетического наслаждения от творческого напряжения своих интеллектуальных и физических сил. Игра, носящая непринужденный характер, опирается на внутреннее побуждение человека и позволяет ему развивать самостоятельность действий. В игре удовольствие приносит не только результат, но и процесс его достижения.

В свете последних тенденций, когда вступил в силу ФГОС ДО, который базируется на основополагающих принципах: поддержка разнообразия детства; сохранение уникальности и самоценности детства, как важного этапа в общем развитии человека; реализация программ дошкольного образования в специфических для дошкольников форме - в игре, познавательной и исследовательской деятельности, творческой активности [2]. Образовательная деятельность в формате квест замечательно вписывается в концепцию, заданную ФГОС ДО. И становится отличной возможностью для педагога и детей увлекательно и оригинально организовать жизнь в детском саду. Квест, с его почти безграничными возможностями, оказывает неоценимую помощь педагогу, предоставляя возможность разнообразить воспитательно-образовательный процесс, сделать его необычным, запоминающимся, увлекательным, веселым, игровым.

\section{Список используемых источников:}

1. Словари ABBYY Lingvo (En-Ru).

2. Приказ Министерства образования и науки Российской Федерации (Минобрнауки России) от 17 октября 2013 г. N 1155 г. Москва "Об утверждении федерального государственного образовательного стандарта дошкольного образования".

3. Сокол И.Н. Классификация квестов // Молодийвчений. 2014. Вып. №6 (09). С. 138-140.

4. Сокол I.М. Квест: метод читехнологія? // Комп'ютер у школі та сім'ї. 2014. № 2(114). С. 28-32. 
5. Щелина Т.Т., Чудакова А.О. Потенциал квеста как педагогической технологии формирования у подростков установки ведения здорового образа жизни // Молодой ученый. 2014. №21.1. С. 146-149.

(C) 2015, Елизарьева Л.В.

Квест как форма организации образовательной деятельности в дошкольном учреждении
(C) 2015, Elizareva L.V.

Quest as a form of educational activity in preschool 